\title{
Tricuspid Valve Hemangioma Associated with Hypoplastic Left Heart Syndrome Presenting as Sudden Infant Death Syndrome
}

\author{
Brijnandan GUPTA ${ }^{1}$, Shouriyo GHOSH ${ }^{2}$, Maikal KUJUR ${ }^{3}$, Khushbu KHETAN ${ }^{2}$, Tarun KUMAR ${ }^{2}$ \\ Department of Pathology, 'Lady Hardinge Medical College, NEW DELHI, INDIA, ${ }^{2}$ All India Institute of Medical Sciences, NEW DELHI, INDIA, \\ ${ }^{3}$ Chhattisgarh Institute of Medical Sciences, Bilaspur, CHHATTISGARH, INDIA
}

\begin{abstract}
Primary cardiac tumors are rare in children with a low incidence varying from 0.0017 to $0.28 \%$ in autopsy studies. Approximately $90 \%$ of the reported primary cardiac tumors in the pediatric population are benign and the most common subtype is rhabdomyomas accounting for approximately $60 \%$, while hemangiomas are rare primary tumors with a 5\% incidence. Hypoplastic left heart syndrome is abnormal development of the left-sided cardiac structures, leading to obstruction of blood flow from the left ventricle out-flow tract. Here we report a case of tricuspid hemangioma in association with hypoplastic left heart syndrome, a rare association not previously reported in the literature.
\end{abstract}

Key Words: Tricuspid valve, Hemangioma, Hypoplastic left heart syndrome, Sudden infant death syndrome

\section{INTRODUCTION}

Primary cardiac tumors are rare in children with a low incidence varying from 0.0017 to $0.28 \%$ in autopsy studies (1). Approximately $90 \%$ of the reported primary cardiac tumors in the pediatric population are benign. The most common subtype is rhabdomyomas accounting for approximately $60 \%$, while hemangiomas are rare primary tumors with a $5 \%$ incidence (2). Hypoplastic left heart syndrome (HLHS) is abnormal development of the leftsided cardiac structures, leading to obstruction of blood flow from the left ventricle out-flow tract. The syndrome also includes underdeveloped left ventricle, aorta, and aortic arch, along with mitral atresia or stenosis. The severity of the degree of obstruction varies among patients (3). Here we report a case of tricuspid hemangioma in association with hypoplastic left heart syndrome, a rare association not previously reported in the literature.

\section{CASE REPORT}

A female neonate was born to a 24-year-old third gravida female at $38+6$ weeks gestation by induced vaginal delivery. The birth weight of the baby was $2.39 \mathrm{~kg}$, which was appropriate for the age. APGAR score was 8 and 9 at 1 and 5 minutes respectively. The baby cried immediately after birth, was alert and active with stable vitals, and did not have icterus or cyanosis. On the second postnatal day of life, the baby was strangely found completely cyanosed at

(Turk Patoloji Derg 2019, 35:55-57)

Received : 19.04.2016 Accepted : 12.05.2016 night and resuscitation was initiated. Despite all efforts, the baby died. A complete autopsy was performed with the clinical suspicion of sudden infant death syndrome (SIDS). At autopsy, no external congenital abnormality was noted. All the organs were in their normal anatomical locations. Milk aspiration was noted in the tracheo-bronchial tree. On dissection, a hypoplastic left heart with small left atrium, poorly developed mitral valve, rudimentary left ventricle, poorly developed ascending aorta and arch of aorta and patent ductus arteriosus were noted. In addition, a brownish hemorrhagic nodule measuring $0.8 \times 0.6 \mathrm{~cm}$ was noted over the tricuspid valve (Figure 1A-C). No other gross anomaly was noted in the internal organs. On histology, this nodule was a cavernous hemangioma (Figure 1D,E) and the myocardium was histologically unremarkable (Figure $1 \mathrm{~F}$ ).

\section{DISCUSSION}

Cardiac hemangiomas are rare and usually detected during imaging or as an incidental finding at autopsy. As observed from Table I, there is no sex predilection with occurrence over a wide age range. The size of the tricuspid valve hemangiomas varies from 0.1 to $3 \mathrm{~cm}$. Usually a single lesion is identified, but rarely it can be multiple $(4,5)$. The mode of presentation of tricuspid hemangiomas can vary from being completely asymptomatic to dyspnoea, regurgitation and even severe cardio-respiratory distress (4-8). Hemangiomas can occur in any portion of the heart

Correspondence: Brijnandan GUPTA

Department of Pathology, Lady Hardinge Medical College,

NEW DELHI, INDIA

E-mail: brij9890470@gmail.com Phone: +01 126882555 

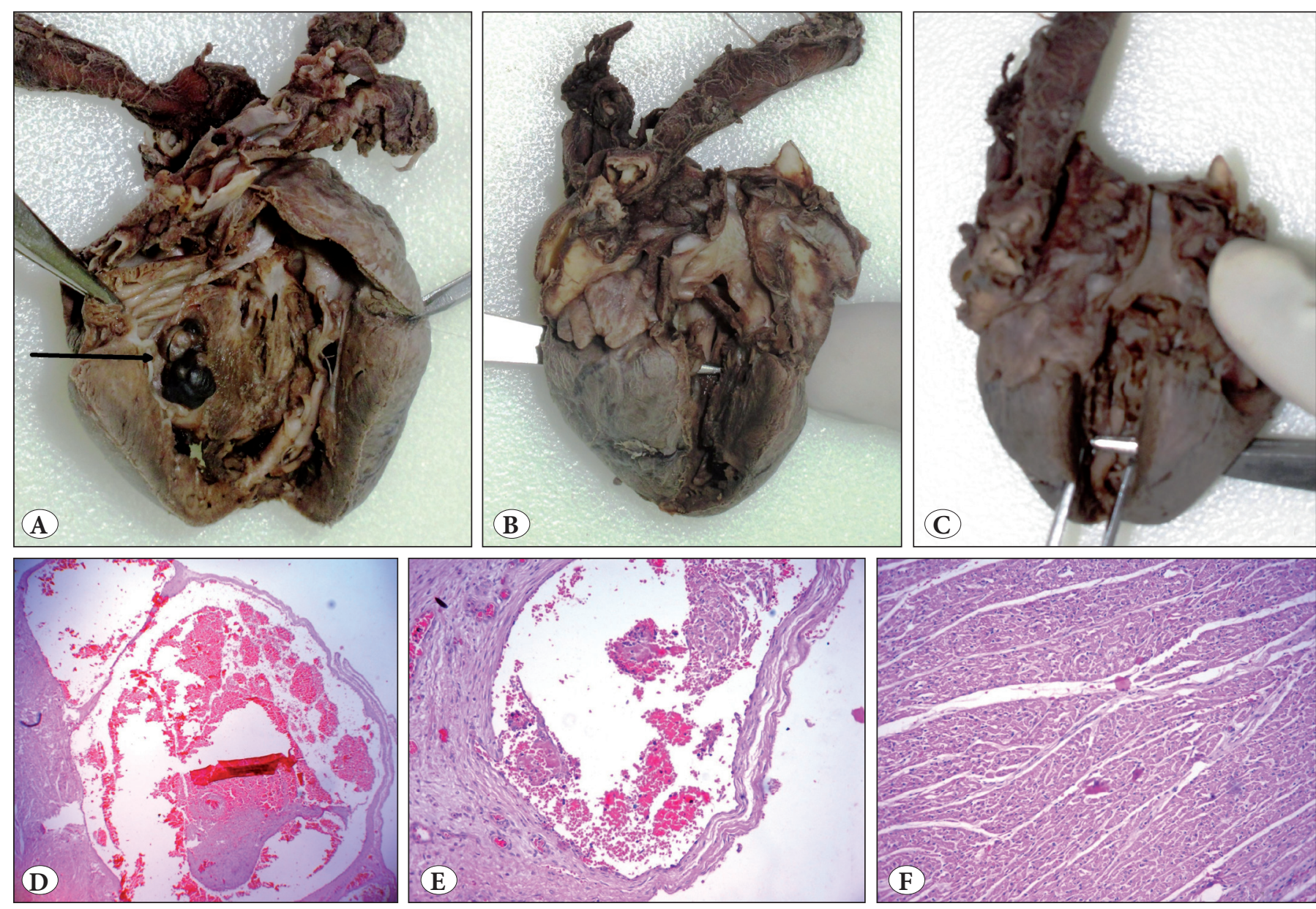

Figure 1: A) Brown nodule over the region of tricuspid valve (arrow) and dilated right side of heart, B,C) Poorly developed and hypoplastic left heart, D) Photomicrograph of the brown nodule shows cavernous hemangioma with multiple vascular channels lined by endothelial cells (H\&E; x40), E) Higher magnification of cavernous hemangioma (H\&E; x100), F) Photomicrograph showing histologically unremarkable myocardium (H\&E; x200).

Table I: Tricuspid valve hemangioma cases reported in the literature

\begin{tabular}{cccccccc}
\hline $\begin{array}{c}\text { Sr. } \\
\text { no }\end{array}$ & Author & $\begin{array}{c}\text { No. of } \\
\text { cases }\end{array}$ & $\begin{array}{c}\text { Age at } \\
\text { presentation }\end{array}$ & Sex & $\begin{array}{c}\text { Maximum } \\
\text { dimension of } \\
\text { hemangioma }\end{array}$ & $\begin{array}{c}\text { Mode of } \\
\text { Presentation }\end{array}$ & Diagnosis \\
\hline 1 & $\begin{array}{c}\text { Lapenna et al. } \\
2003\end{array}$ & 1 & 49 years & Female & $3 \mathrm{~cm}$ & $\begin{array}{c}\text { Syncope \& tricuspid } \\
\text { regurgitation }\end{array}$ & $\begin{array}{c}\text { Transesophageal } \\
\text { echocardiogram }\end{array}$ \\
\hline $2 \& 3$ & $\begin{array}{c}\text { Ray et al. }{ }^{6} \\
2004\end{array}$ & 1 & 47 years & Male & $1 \mathrm{~cm}$ & $\begin{array}{c}\text { Recurrent dyspnea } \\
\text { after exertion }\end{array}$ & Echocardiography \\
\cline { 2 - 7 } & 1 & 1 day & Male & $\begin{array}{c}0.1-0.4 \mathrm{~cm} \\
(\text { Multiple })\end{array}$ & $\begin{array}{c}\text { Severe cardio- } \\
\text { respiratory distress }\end{array}$ & Incidental at autopsy \\
\hline 4 & $\begin{array}{c}\text { Wong et al. }{ }^{7} \\
2004\end{array}$ & 1 & 4.5 years & Female & $0.8 \mathrm{~cm}$ & $\begin{array}{c}\text { Systolic murmur } \\
\text { and cyanosis }\end{array}$ & Echocardiogram \\
\hline 5 & $\begin{array}{c}\text { Cannata et al. } \\
2010\end{array}$ & 1 & 76 years & Male & $2 \mathrm{~cm}$ & $\begin{array}{c}\text { Asymptomatic } \\
\text { echocardiography }\end{array}$ \\
\hline 6 & $\begin{array}{c}\text { Floria et al. }{ }^{9} \\
2011\end{array}$ & 1 & 52 years & Female & $1.6 \mathrm{~cm}$ & $\begin{array}{c}\text { Palpitations and } \\
\text { atypical left chest pain }\end{array}$ & $\begin{array}{c}\text { Transthoracic } \\
\text { echocardiography }\end{array}$ \\
\hline 7 & Index case & 1 & 2 days & Female & $0.8 \mathrm{~cm}$ & Cyanosis & Incidental at autopsy \\
\hline
\end{tabular}


including the wall of the chambers or valves and grossly appear as red to brown hemorrhagic nodules. However, hemangiomas at the valve region are relatively rare. On microscopy, cavernous hemangiomas show dilated vascular channels lined by endothelial cells. Tricuspid hemangiomas have been detected incidentally during echocardiography or at autopsy and in most of the cases this was an isolated finding in the heart without other significant cardiac pathology. The present case had simultaneous occurrence of two extremely rare lesions of the heart, i.e. tricuspid hemangioma and HLHS, which has not been documented earlier in the literature. The diagnosis of a cardiac tumor in the neonatal age group is difficult due to nonspecific presenting symptoms. Transthoracic echocardiography is an important diagnostic investigation for detecting cardiac masses and is helpful in assessing the need for surgery. Treatment of cardiac hemangiomas is primarily aimed at surgical removal and repair. There are no data available on the recurrence risk of cardiac hemangiomas and serial echo studies are recommended to detect recurrence.

HLHS is a condition in which the left-sided structures (mitral valve, left ventricle, aortic valve, aorta) are rudimentary and inadequate to support the systemic circulation. HLHS has been reported to occur in approximately 0.016 to $0.036 \%$ of all live births (9). It may be associated with an intact atrial septum or atrial septal abnormalities, the latter being crucial for better prognosis after corrective surgery. HLHS with an intact atrial septum is associated with dismal survival even after corrective surgery due to its complex hemodynamics and altered pulmonary physiology (10). As the brain and head-neck region is supplied by an inconsistent retrograde flow of blood from the PDA into the arch of the aorta, these fetuses usually have microcephaly and neurodevelopmental anomalies due to a chronic hypoxemic state both in-utero and after birth. Early in-utero diagnosis of this condition may help to perform timely interventions that improve survival rates and prevent neurologic sequelae in the survivors. The cause of death in the index case can be attributed to HLHS. The importance of diagnosing this condition either in the antenatal period or at autopsy is to prevent recurrences in subsequent pregnancies, the risk of which is considerably increased (10). The hemangioma in this case was an associated finding, and may have aggravated the abnormal hemodynamics by causing tricuspid regurgitation in an already compromised heart. SIDS was ruled out in the index case in view of significant findings in the heart. It can be said with considerable conviction that these hemangiomas are not silent, as all except one previously reported case were symptomatic (48). In conclusion, tricuspid valve hemangioma is extremely rare with only six cases previously reported in the literature. The association between tricuspid valve hemangioma and hypoplastic left heart syndrome is unique. The onus is to develop next generation interventional fetal medicine for the management of such cases and to improve the outcome.

\section{REFERENCES}

1. Rodrigues D, Sá e Melo A, Loureiro M, da Silva AM, Antunes M, Providência LA. Cardiac tumors in the pediatric age group-case reports. Rev Port Cardiol. 2005;24:1509-15.

2. Uzun O, Wilson DG, Vujanic GM, Parsons JM, De Giovanni JV. Cardiac tumours in children. Orphanet J Rare Diseases. 2007;2:11-24.

3. Anderson RH, Smith A, Cook AC. Hypoplasia of the left heart. Cardiol Young. 2004;14 Suppl 1:13-21.

4. Lapenna E, De Bonis M, Torracca L, La Canna G, Dell'Antonio G, Alfieri O. Cavernous hemangioma of the tricuspid valve: Minimally invasive surgical resection. Ann Thorac Surg. 2003;76:2097-9.

5. Ray R, Rishi A, Venugopal P, Chopra P. Hemangioma of the tricuspid valve: A report of two cases with review of literature. Cardiovasc Pathol. 2004;13:120-2.

6. Wong KK, Sandor GG, Sett SS. Isolated haemangioma of the tricuspid valve. Cardiol Young. 2004;14:324

7. Cannata A, Russo CF, Merlanti B, Pedrotti P, Moreo A, Botta L, Martinelli L. Cavernous hemangioma replacing the septal leaflet of the tricuspid valve. J Card Surg. 2010;25:524-7.

8. Floria M, Guedes A, Buche M, Deperon R, Marchandise B. A rare primary cardiac tumour: Cavernous hemangioma of the tricuspid valve. Eur J Echocardiogr. 2011;12:477.

9. Samánek M, Vorísková M. Congenital heart disease among 815,569 children born between 1980 and 1990 and their 15-year survival: A prospective Bohemia survival study. Pediatr Cardiol. 1999;20:411-7.

10. Rychik J. Hypoplastic left heart syndrome: From in-utero diagnosis to school age. Semin Fetal Neonatal Med. 2005;10:55366. 